The Aesthetic and its relationship to business ethics: Philosophical underpinnings and implications for further research

\title{
Ladkin, DM
}

http://hdl.handle.net/10026.1/10894

10.1007/s10551-015-2928-2

Journal of Business Ethics

Springer Verlag

All content in PEARL is protected by copyright law. Author manuscripts are made available in accordance with publisher policies. Please cite only the published version using the details provided on the item record or document. In the absence of an open licence (e.g. Creative Commons), permissions for further reuse of content should be sought from the publisher or author. 
'The Aesthetic' and its Relationship to Business Ethics: Philosophical Underpinnings and Implications for Future Research

Submitted to the Journal of Business Ethics

\author{
Dr Donna Ladkin \\ Professor of Leadership and Ethics \\ Graduate School of Management \\ Plymouth University \\ Drake Circus \\ Plymouth; PL4 8AA \\ UK \\ $+441752585614$ \\ Donna.Ladkin@plymouth.ac.uk
}




\title{
'The Aesthetic' and its Relationship to Business Ethics: Philosophical Underpinnings and Implications for Further Research
}

\begin{abstract}
The article clarifies the way in which 'the aesthetic' is conceptualised in relation to business ethics in order to assess its potential to inform theory building and developmental practices within the business ethics field. A systematic review of relevant literature is undertaken which identifies three ontologically-based accounts of the relationship between the aesthetic and business ethics: 'positive' ones (in which 'the good is equated with 'the beautiful'), 'negative' accounts (in which aesthetic craving is seen to foster ethical malfeasance) and 'post modern' renderings (in which the aesthetic and the ethical are seen to be ideologically informed). Five epistemologically based approaches are also made explicit: those in which the aesthetic is thought to develop enhanced perceptual discernment, those in which the aesthetic catalyzes emotional sensitivity, those in which the aesthetic contributes to imaginative capacity, those in which the aesthetic prompts integrative apprehension, and those in which the aesthetic is seen to foster critical reflexivity.
\end{abstract}

The review reveals two key findings: firstly, the dearth of empirically based research to substantiate claims made about the aesthetic's ability to foster ethical capabilities, which leads to proposals for further research. Secondly, the analysis indicates the significance of critical reflexivity both in resolving the apparent dichotomy between ontologically based perspectives asserting the aesthetic's ability to lead to ethically sound or egregious behaviour, and in underpinning the capacities of perceptual discernment, emotional connectivity, imagination and integrative apprehension which epistemologically based approaches assert the aesthetic can foster.

Keywords: Aesthetics, aesthetic sensibility, art-based methods, ethical astuteness, ethical development 


\section{The Aesthetic' and its Relationship to Business Ethics: Philosophical Underpinnings and Implications for Further Research}

Within the business ethics literature, a growing number of scholars are exploring the connection between aesthetics and ethics ( Brady, 1986, Brady and Hart, 2006; Dobson, 2007, 2010; Issa \& Pick, 2010, 2011; Koehn \& Elm, 2014; Ladkin, 2011; Waddock, 2010, 2014) Close reading of their writing, however, reveals different meanings underpinning their understanding of 'the aesthetic'. For instance, aesthetics can be seen to encompass capacities ranging from an appreciation of 'honesty, integrity, support, and compassion' (Issa \& Pick, 2010: 619) to a way of encouraging 'perspective taking' (Moberg \& Seabright, 2000) to a means of developing the ability to 'transcend opposites and contradictions' (Brady \& Hart, 2006). Moreover, whereas the majority of scholars theorize the connection between aesthetics and ethics as inherently beneficial, others highlight the hedonistic aspects of aesthetic indulgence which can lead to ethical malfeasance (Kersten, 2008; Storsletten \& Jakobsen, 2014) Without clarification, 'the aesthetic' is in danger of becoming conceptually diluted to the point of meaning 'everything and nothing' thus offering nothing distinctive to the field of business ethics.

The paper aims to clarify the way in which the aesthetic is conceptualised in relation to business ethics in order to assess its potential to inform theory building and developmental practices within the business ethics field. This is accomplished through a systematic literature review which reveals the ways in which the aesthetic is defined as well as linking definitions to their underpinnings from Western philosophy. In undertaking this work, the article 
provides a comprehensive view of the field and its philosophical underpinnings which has been previously missing.

The paper proceeds as follows: the argument is positioned within the wider fields of organizational aesthetics and business ethics. The method for interrogating literature is described. A map which distinguishes between different ontological and epistemological accounts of the relationship between the aesthetic and ethics is offered, linking each position taken with its philosophical roots. The implications of the map are discussed, noting particularly the reasons for turning to the aesthetic in relation to business ethics, the current lack of empirical research to substantiate claims made within the literature, and the key role of 'critical reflexivity' for both ontological and epistemological renderings. The paper ends by proposing a systematically derived programme of empirical research in order to further assess the potentialities of the aesthetic in relation to business ethics.

\section{POSITIONING AESTHETICS WITHIN BROADER ORGANIZATIONALLY BASED LITERATURE}

The interest in aesthetics and its connection with business ethics is indicative of more general explorations of aesthetics within the larger field of organization studies. In his article concerning the benefits of a semiotic approach to aesthetics, Hancock (2005) offers a thorough account of the history of the 'aesthetic turn' within organizational studies. In it he suggests that current interest in 'the aesthetic' as a way of understanding organizations is 'profoundly in tune with the post-rationality of both post excellence management thinking and post modern academic thinking (Hancock, 2005, p. 30). Scholars in the organizational aesthetics field such as Antonio Strati (Strati, 1992, 1999), Pierre Guillet de Monthoux (Guillet de Monthoux, 2000), Steven Taylor (Taylor, 2002) and Stephen Linstead and Heather Hopfl (Linstead \& Hopfl, 2000) offer a range of views concerning the benefits of using the lens of aesthetics to analyze, interpret, and create organizational forms. Common to 
all of them however is the understanding that 'the aesthetic' (defined as a type of pre-rational, embodied knowing) provides an alternative to the hyper-rationalistic ways in which organization studies has previously been theorized.

In the field of business ethics, the suggestion that the aesthetic might have something to contribute to how business ethics is theorized can be traced to Brady's (1986) paper in the Academy of Management Review. In that paper Brady offers 'the aesthetic' as a way into 'know how' - an idea linked to that of tacit knowledge gaining popularity at that time. Since then, 'the aesthetic' arises periodically within the business ethics literature, but in the last ten years, growing interest in the topic is evidenced by a Special Issue in Tamara, Critical Studies in Management in 2012, as well as Koehn and Elm's book Aesthetics and Business Ethics published in 2014. However, as intimated in the opening section of this article, there is significant variation in the way the aesthetic is conceptualized among these accounts, with corresponding disparity in the way the aesthetic is seen to relate to business ethics.

Differences of terminology itself are apparent; as well as writing of 'the aesthetic'; 'aesthetic judgement' ( Brady, 1986; Issa \& Pick, 2010) 'aesthetic perspective' (Dobson 2007) 'aesthetic sensibility'(Waddock 2014) and 'aesthetic reflexivity' (Ewenstein \& Whyte, 2007) are also used.

In approaching the relationship between the aesthetic and business ethics it is interesting to speculate on why the relationship between the two is receiving increasing attention. In his analysis, Cummings (2000) purports that as the limitations of rule-based, generalized approaches to business ethics become more apparent, we must turn to other approaches which allow more particularized consideration. The aesthetic, with its basis in subjectivity and attention to 'quality' offers such an alternative. This idea is echoed in the works of Green (1993) and Dobson (2009). 
This turning to the aesthetic in relation to the ethical is not new however. Within the Western philosophical canon the relationship between them has been theorized since Plato aligned 'the good' with 'the beautiful' in dialogues such as Phaedrus, Hippias Major and The Republic (Plato, 1966). Following from Plato, the interconnection is explored by Western philosophers ranging from Kierkegaard (1956)to Foucault (1984). Although many of those exploring the aesthetic in relation to business ethics do cite the particular philosopher from whom their work draws, a way of understanding how these thinkers' works relate to one another, and thus to broader discussions concerning the aesthetic, is lacking. This paper seeks to address this missing comprehensive view.

Stepping back momentarily to consider the meaning of 'the aesthetic' itself, it is clear that 'the aesthetic' is often linked to notions of 'the beautiful', and in popular consciousness is also associated with notions of 'art'. A much broader understanding of the term which recognizes the aesthetic as arising from sense perception more generally, rather than just in response to the beautiful can also be seen within philosophical accounts. For instance, in her essay, 'Aesthetics and Walter Benjamin', the philosopher Susan Buck-Morss reminds us that the etymology of the word 'aesthetics' is the Greek, aisthisis, which literally means 'perception by feeling'(Buck-Morss, 2008). She explains further, 'aisthisis is the sensory experience of perception. Accordingly, the original field of aesthetics is not art but reality, corporeal, material' (p.6). Duwell provides additional clarification by suggesting that the move from sensorily based perception as meant by the word 'aisthetics' becomes 'aesthetics' through 'philosophical reflection on aesthetic phenomenon'(Duwell, 1999, p. 161). From this perspective, we are always having aisthetic experiences: the warmth or chill of the air, the smell of bacon frying or the hyacinth that is blooming in the garden, the twittering of birds or the low growl of a truck's engine lumbering up the hill. Those smells, feelings of 
heat or cold, sounds of birds or engines - are all aisthetic experiences. By noticing and reflecting on them, they become 'aesthetic' experiences.

Following from this understanding of the term, Buck-Morss explains that the aesthetic is not solely connected to 'the beautiful', nor is it primarily associated with the arts or artwork. Instead, aligned with Dewey (1934[2005]) she equates 'the aesthetic' with our felt experience of existing and perceiving that existence which imbues every moment of our lives. In exploring how aesthetics is theorized within the business ethics literature both the understanding of the aesthetic as way of appreciating 'art' or 'artfulness' and as an embodied way of knowing are evident. Seldom, however, is the distinction between these ways of conceptualizing the aesthetic explicitly made. It is important to recognise these underpinning assumptions, because conceptualizing the aesthetic as 'art appreciation' has different consequences for thinking about 'ethics' than theorizing it as a way of knowing. Each brings different insight into ethical enactment. For instance, when thinking of the ethical as somehow equivalent to the aesthetic, or the beautiful, attention will be focused on 'what is beautiful here?' Whereas when thinking of the aesthetic as a way of knowing, attending to one's own experience and sense of the situation becomes paramount. The next section of the paper elaborates on these distinctions by examining how they appear in current business ethics literature.

\section{INTERROGATING THE LITERATURE}

\section{Method}

Four data bases (EBSCO, ABI, Google Scholar and the Worldwide Web of Knowledge) were interrogated using the search terms aesthetics, aesthetic sensibility, aesthetic judgement, art and art-based methods intersected with business ethics, ethics and their variations. A total of 118 papers were identified. This broad search also produced a 
number of papers exploring the relationship between the aesthetic and ethics within the fields of education and medicine. These are included in the review, as the issues raised within them were also seen to be central to those within the business context. After discarding replications and those that did not meet relevance criteria ${ }^{\mathrm{i}}, 31$ sources remained within the survey. These are included in Appendix A.

Table 1 below provides a summary of the descriptive statistics for the sources used in the review.

\section{[Insert Table 1 Here]}

It can be seen from this Table that indeed, there has been growing interest in the intersection of the aesthetic and business ethics since 2006. Also, the vast majority of these papers remain at the theoretical level, suggesting the need for more empirically-based studies to test theoretically derived ideas. The range of philosophical underpinnings used is also noteworthy; with Kant cited most frequently as a source of theoretical insight. It is also striking that a third of the papers reviewed do not explicitly link their arguments with any particular philosophical (or psychological, sociological, or anthropological) grounding. Two broadly-based aims were identified: papers either purported to show how considerations of 'the aesthetic' (usually conceptualised as 'the beautiful') could inform what was 'ethical' in a given situation, or they proposed ways in which the aesthetic could develop ethical capacities, such as moral perception or compassion.

Each article or chapter was analyzed to establish the way in which the aesthetic was defined and the way in which the connection to business ethics was constructed. From this reading, categories were developed, grouping the way in which authors made sense of the terms and relationships as follows: Firstly, a primary distinction was made between ontologically based accounts of the relationship between the aesthetic and ethics, and 
epistemologically based accounts. Within ontologically-based accounts, a further three distinctions can be discerned:

- 'Positive' accounts, linking 'the good' with 'the beautiful'(Bathurst \& Edwards, 2011; Brady, 1986; Dobson, 2007, 2010, 2014; Koehn \& Elm, 2014b; Taylor \& Elmes, 2011);

- 'Negative' accounts - suggesting the aesthetic causes cravings which can lead to bad behaviour ( Kersten 2008; Storsletten \& Jakobson 2014);

- Post modern accounts, in which the aesthetic and the ethical are both part of the postmodern movement and determined by prevailing ideologies (Cummings, 2000; Green, 1993).

Epistemological renderings of the link between the aesthetic and the ethical can be categorized into five approaches:

- Those in which the particular 'knowing' afforded by the aesthetic concerns enhanced perceptual discernment (Bleakley, Farrow, Gould, \& Marshall, 2003; Brady \& Hart, 2006; Issa \& Pick, 2010, 2011; Koehn, 2010; Waddock, 2010);

- Those for whom aesthetic knowing catalyses emotional sensitivity (Abowitz, 2007; Carr, 2004; Koehn, 2014; Moberg \& Seabright, 2000);

- Accounts in which aesthetic knowing is linked to the development of imaginative capacity (Collier, 2006; Ladkin, 2011, Blumenfeld-Jones 2013);

- Accounts in which the aesthetic cultivates 'integrative apprehension'(Abowitz, 2007; Koehn, 2010; Kokkos, 2010; Waddock, 2010);

- Accounts in which aesthetic knowing is seen to foster 'critical reflexivity'(Caranfa, 2007; Duwell, 1999; Elm, 2014; Ewenstein \& Whyte, 2007; Kimbell, 2011; Waddock, 2014). 
The next section of the paper elaborates on these distinctions, beginning with the ontologically-based categories.

\section{Ontologically Based Accounts}

In suggesting that an article has presented an 'ontologically-based' account, the nature of 'the ethical' and the nature of 'the aesthetic' are seen to be aligned. In other words, the ethical and the aesthetic are seen to be the same sort of phenomena. For these writers, it is seeing the ethical in relation to the aesthetic that provides particular insights into the ethical. This idea becomes clearer by exploring the different ways in which they are seen to be ontologically linked.

\section{The Good and the Beautiful}

Perhaps the link between the aesthetic and ethics which most readily comes to mind is derived from the understanding that 'the good' and 'the beautiful' are inherently aligned. This is a notion that hearkens back to Plato who in determining the ideal of 'the beautiful' draws its connection to the good in his dialogue Hippias Major (in Carritt 1966). The indicative part of the dialogue is as follows:

S: And so beautiful bodies and beautiful ways and wisdom and all the things we mentioned just now are beautiful because they are profitable.

H: Clearly.

S: So we agree that profitableness and beauty are identical?

H: Certainly.

S: But what is profitable is what produces something good.

H: Yes. 
$S:$ Then if beauty is the cause of goodness, goodness would be produced by beauty; and that, it seems is why we value right-mindedness and all other beautiful qualities, because their end result and offspring, which is the good, is valuable. And our conclusions seem to show that what is beautiful is a kind of father to what is good (Plato, 1966, pp 11-12).

Plato explores the relationship between 'the beautiful' and 'the good' in other dialogues as well, most notably Phaedrus and in his Republic. It is important to remember that central to Plato's philosophy was the determining of 'ideals', abstracted pure forms which serve as universals to which 'particulars' can be compared. The ideals of 'the beautiful' and 'the good' are in his philosophy related through the notion of 'purified mind'. The connection between the good and the beautiful is also elaborated by the neo-Platonist Plotinus (Plotinus, 1984), the theologian Thomas Aquinas and explored throughout Western philosophy by scholars ranging from Frederick Schiller (Schiller, 1795/1967) to Iris Murdoch (Murdoch, 1970).

In the business ethics literature, this ontological connection is apparent in the writings of Bathurst \& Edwards (2011)Brady (1986), Koehn \& Elm (2014), Dobson (2007) and Taylor \& Elmes (2011). For instance, drawing from Hartshorne (1974), Brady (1986) suggests that the 'criteria for what is 'good' is what is 'aesthetic'. In their introduction to Aesthetics and Business Ethics, Koehn \& Elm similarly assume the link between the ethical and the aesthetic to be an ontological one, tracing the connection as posited by Greek, Chinese and Japanese traditions (Koehn \& Elm, 2014). Dobson (2007) argues that when judging what is 'good' for a firm to do, the question, 'what is beautiful?' provides a useful guide.

Most of these writers do not explicitly articulate a definition of 'the beautiful' or 'the aesthetic'. The reader is largely left to interpret the meaning of these terms for him or herself. 
Indeed, for those such as Koehn \& Elm who use the term 'the aesthetic' rather than 'the beautiful', categories of aesthetic experience, such as 'the sublime', 'the comic', or even 'the ugly' are not considered. The possibility that the aesthetic could lead to outcomes other than 'the good' is not mentioned. This is in contrast to other authors, who align 'the aesthetic' with the kind of hedonism or craving which leads to ethical malfeasance.

\section{The Aesthetic aligned with hedonism}

From an opposing perspective, three scholars within the survey focus on the aesthetic's link to sensuality and hedonism. For them, aesthetically based cravings can result in ethical malfeasance. The key philosopher informing this view is Soren Kirkegaard, who posits four spheres of human behaviour: the pre-ethical, the aesthetic, the ethical and the religious (Kierkegaard, 1956). For him, the nature of the aesthetic and that of the ethical are not aligned but are ontologically opposed to one another.

The business ethics scholars Kersten (2008) and Storsletten and Jakobsen (2014) use this understanding of the aesthetic to underpin their arguments that the aesthetic can lead individuals into, rather than away from ethical malfeasance. Similarly, Storsletten and Jakobsen follow Kierkegaard in theorizing the aesthetic and the ethical as fundamentally 'different ways of being'. They cite Gardiner (2002) who explains that for Kierkegaard, 'the man who lives aesthetically is not really in control, either of himself or his situation, he tends to live in the moment, for whatever the passing instant will bring in the way of entertainment, excitement or interest' (Gardiner 2002, p. 48). Kersten takes a slightly different approach, which will be elaborated further in the section concerning 'post modern' renderings.

In summary, within these two ontologically based categories, business ethics scholars show the aesthetic to be implicated in both 'good' and 'bad' ethics. Rather than suggesting one account is more correct than the other, it may be helpful to consider the way in which 
each conclusion is reached. For ontological accounts equating the 'good' with 'the beautiful', each is seen as an 'ideal', arising from a 'purified mind', as suggested by Plato. In contrast, Storsletten and Jakobsen maintain that rather than being an ideal, the nature of the aesthetic is such that its basis in the senses leads to uncontrollable desires and hence to unethical behaviour.

It is tempting to ask which account is correct - that which aligns the aesthetic with the good or that which sees them as ontologically opposed? Certainly this is an important question for those considering using 'the aesthetic' in order to pursue ethical developmental objectives. The last of the ontologically based renderings, that of the post-modern, may suggest a way of resolving this apparent dichotomy.

\section{Post modern renderings of the aesthetic and the ethical}

In his Business Ethics Quarterly article of 1993, Green suggests that the interest in the aesthetic in relation to business ethics is indicative of the encroachment of post modernism into the world of organizations (Green, 1993). Both, he suggests reject the 'grand narratives' apparent within modernism, and they both strive to involve 'multiple voices' in coming to judgements. Cummings ( 2000) and Munro (2014) develop Green's argument further by drawing from Foucault's work concerning the 'art of living' (Foucault 1984).

In rejecting the grand narrative inherent within deontological approaches, Foucault suggests that life itself should be a 'work of art', and the beauty of that work of art should be determined by the work's telos (see Rabinow, 1986). In this way, the account of the aesthetic is dependent on the subject's telos - that is, what it is supposed to be. Similarly for Foucault, what is ethical for a person to do is dependent on their position within a community and what is destined to be in that community. In this way, aesthetics and ethics work alongside one another and are determined by the kind of person what one is striving 'to be'. 
Drawing from the political philosopher Kateb (2000), Kersten (2008) reminds us though that 'what one is striving to be' is itself often grounded in ideologies, rather than 'truths'. She points out that 'what appears to us as beauty, morality, and truth is always contextual and often ideological (Kersten, 2008, p. 191) and urges vigilance in accepting such ideals uncritically. For her, the case of Enron can be explained by 'hyperactive imagination at its operational best, reflected in the mission of the organization, its vision, bold strategy and its celebration of itself and its excellence (p. 196).

For Cummings, Green, Kersten and Munro then, the aesthetic offers alternative guidance to those seeking to make sound ethical judgement in a world in which deontological, rule-based approaches to business ethics are left wanting. They also move beyond the 'beauty equals good' or 'the aesthetic leads to bad' dichotomy by highlighting the way in which both the aesthetic and the ethical are particularized and subject to larger contextually based dynamics and flows. For them, criticality is essential in making both aesthetic and ethical judgements, an idea to which the paper will return.

\section{Epistemologically based accounts}

The appreciation of the aesthetic from an epistemological perspective has its roots in the work of the $18^{\text {th }}$ century German philosopher Alexander Baumgarten, who, along with being credited with coining the term 'the aesthetic', argues that it should not first be related to 'art', but to 'the whole region of human perception and sensation' (Baumgarten, 1750, reprinted 1936). As such, the aesthetic offers a distinct way of knowing, one in contrast to rationally based conceptual knowing and grounded in a 'discourse of the body' (Eagleton, 1990, p. 13). The post-modern philosopher Jerrold Levinson (1998) elaborates on the notion of aesthetics as a way of knowing, and for him it is this epistemological orientation which provides the connection between aesthetics and ethics. He argues that at their core, both 
ethics and aesthetics are 'branches of value theory'. That is, they both provide a means by which judgements are made. Within the arena of ethics judgements are made between 'right' and 'wrong', the best way of handling interpersonal relations, or questions of broader social relations. Within the realm of aesthetic knowing, judgements are made concerning quality and affect. Understood in this way, the potential epistemological link between 'aesthetics' and 'ethics' becomes apparent: they both require 'knowing' aimed at attending to data in a particular way, and discriminating in order to make judgements about actions or desired affects.

Roughly half of the articles included in the review see the aesthetic as offering particular strengths in developing ethical capabilities and thus approach the aesthetic from an epistemologically based stance. However, inspection of the way in which authors describe the form of knowing available through the aesthetic reveals a range of different 'knowings' which it supposedly fosters. For instance, Carr (2004, p. 225) writes that it is 'that which prompts us to be attached to something beyond ourselves (Carr, 2004, p. 225), whereas Kokkos (2010, p. 157) suggests it is [that which] 'enables participants the possibility to process a variety of symbols through which it is possible to articulate holistic and delicate meanings'. The variety of meanings underpinning the use of these terms can be grouped in five ways: as perceptual discernment, as a way of catalysing emotionally-grounded sympathy, as a means by which imaginative capacity can be developed, as a stimulus for achieving integrated apprehension, and as a way of fostering critical reflexivity. Each of these epistemological renderings is described in greater detail below.

\section{Aesthetic sensibility as perceptual discernment}

A number of authors clearly equate aesthetic sensibility with an enhanced way of perceiving that is by considering aspects of balance, harmony, and tension resolution in the 
way that aspects of a composition (or situation) relate to one another. For instance, Brady and Hart (2006) draw from Scitovsky (1976) and Siegel (1946) to highlight the importance of being able to discern the 'balancing point' at which tensions are resolved in both aesthetic and ethical realms. They suggest that 'the great administrator does what the good artist does. He or she creatively balances the influences of all ethical voices in the organization' (2006, p. 127).

A similar assumed link between the two is also apparent in Sandra Waddock's work, but with a slightly different emphasis in terms of the visual capacities the aesthetic affords ethical capabilities. For Waddock, aesthetic sensibility is an aspect of 'wisdom' (2014, p. 129) along with moral imagination and systems understanding. It is a critical capacity for becoming aware of the design and aesthetic implications of a situation. In this way, it seems primarily implicated in the discernment of balance and harmony and the achievement of a sensually pleasing 'ideal' (2014, p. 135). This emphasis on aesthetic sensibility as a means for achieving harmony is apparent in two of the four characteristics of it she identifies:

- Understanding the relationships among elements in a system (including people as well as systems elements)

- The capacity to balance conflicting elements (with the greater good in mind) (Waddock, 2014, p.141).

Attending to how one might achieve balance, harmony, proportion, and fitness to purpose is central to Waddock's understanding of systems thinking. Within these writers' work then, 'aesthetic sensibility' requires the ability to discern harmony and balance in a way anomalous to that required of anyone trying to achieve optimally functioning designs. This conception of aesthetic sensibility is also apparent within Issa and Pick's empirical work into 'ethical mindsets'(Theodora Issa \& Pick, 2010). They discovered that in describing ethical 
judgement, their research participants referred to 'fairness, balance, and harmony' as three key aspects of aesthetic judgement associated with having an ethical mindset.

The kind of discernment apparent in these accounts resonates with Kantian notions of aesthetic judgement apparent in his Critique of Judgement (Kant, 1790[2005]). In particular, when discerning something to be beautiful, the perceiver is attentive to feelings of pleasure that arise from contemplating the object (Burnham, 2000, p. 40). Apprehension of a particular way in which a situation or object is designed is key here, for as Budd suggests, 'the feeling of pleasure associated with a beautiful work of art emerges from a sense of the various characteristics of the object cohering in a seemingly intentional and well-fitted manner (Budd, 2001: 251). It is this kind of apprehension, of the sensation of 'balance, harmony, and resolution, which seems to be at the heart of perceptually based aesthetic knowing written about by Waddock, Issa and Pick, and Brady.

Others however, note the way in which the aesthetic prompts connections which arise from an emotional response, rather than one based on perceptual discernment, as described in greater detail in the next section.

\section{Aesthetic sensibility as a catalyst for emotional response}

In her book chapter describing her students' response to Michael Moore's film, Roger and Me, Koehn (2014) suggests that both aesthetic sensibility and ethical deliberation draw on the ability to engage emotionally. Koehn makes the point that as a medium, film 'is able to widen the net of accountability to include the reviewer... thus creating an emotional (my emphasis) connection which allows the viewer to put themselves into the shoes of another in a way that 'telling' people what to do ethically does not' $(2014$, p.100). She suggests that aesthetic media prompt us to pose questions, and these questions are 'more likely to touch our hearts and to stay with us if we ask them by, of, and about ourselves' (pp100-101). Moberg 
and Seabright (2000) echo this view suggesting that because of their ability to move us deeply, the arts can help in the development of moral imagination and perspective taking. Writing from the field of education, Carr suggests that aesthetic appreciation 'prompts us to be attached to something beyond ourselves' $(2004$, p. 225) further arguing that it is a type of 'sensitivity' which enables this connection to be made. Elm goes as far as to suggest 'passion and emotion' as one of the four key practices exercised by artists and one which should also be applied to ethical astuteness.

The importance of the kind of emotional engagement proposed to be catalysed by the aesthetic in making sound ethical judgements is apparent in the philosophical literature from the time of Aristotle. Martha Nussbaum writes that for Aristotle, 'emotions are not simply blind surges of affect...rather they are discriminating responses closely connected with beliefs about how things are and what is important' (Nussbaum 1990, p. 41). Nussbaum herself promotes the importance of emotional connection to sound ethical decisions, suggesting that 'emotions are an intelligent part of our ethical agency, responsive to the workings of deliberation and essential to its completion.' (1990, p. 41). The need for emotional engagement in order to make sound ethical judgements is particularly apparent in writing from the 'ethics of care' tradition (Gilligan, 1982; Noddings, 1984), in which empathetic response to the other is so highly prized. Hannah Arendt goes as far as to assert that if we do not experience an emotional reaction in response to the suffering of others, there is something wrong with us (Arendt, 1998)

The key point here is: if aesthetic sensibility is understood to be a means by which emotional engagement is aroused and experienced, then it is through this kind of emotional arousal the type of empathetic engagement required of ethical caring can be fostered. This is the largely unstated assumption which underpins the writings of those quoted here who use aesthetically-based learning methods within their teaching of business ethics. 
It is also useful to remember though that for every writer who sees emotions as vital to ethical discernment there are many others who consider them to be 'highly suspect' in relation to sound deliberation. Plato considered passion to be a 'form of intoxication' (see Ion or The Republic Book X) and the appropriateness of reason, rather than sentiment in moderating ethical judgements is of course central to Kant's writings. Viewing objective rationality as the pinnacle of ethical maturity is the culmination of Kohlberg's work on ethical development (Kohlberg, 1984) and is apparent in the models and frameworks derived from his work, including the ever popular 'four part behavioural model of ethical action' developed by Rest (1986). This debate concerning the helpfulness or not of the emotions in coming to sound ethical decisions and action is perhaps reminiscent of the controversy concerning the extent to which 'the aesthetic' itself fosters appropriate or inappropriate behaviour. The implications of both of these debates will be elaborated in the discussion section of the paper. Now however, let us turn to a third type of 'knowing' purported to be fostered by 'the aesthetic', 'imaginative capacity'.

\section{Aesthetic Knowing as a way of prompting imaginative capacity}

The 'imaginative', and the 'emotional' are very closely linked and for authors such as Abowitz (2007), it is the aesthetic's ability to prompt an imaginative leap into another's circumstances which forms the basis of emotionally connecting with them. However, here they are separated into two distinct ways of knowing because although there is indeed overlap between them in the literature, there are still aspects of difference worth teasing apart.

For instance, in her examination of moral imagination in architectural practice Collier (2006) emphasizes the importance of imagination in moral judgement and refers to the pragmatist philosopher John Dewey in suggesting that the imagination enables us to 'understand the actual in light of the possible (p.371). As such, it involves a cognitive leap 
which may or may not be ignited through emotional connection. Similarly, in trying to foster imaginative engagement within her trainee teachers Abowitz takes them to see Philip Morsberger's painting, 'Hey Let's Have Some Redman/The Arraignment' which depicts the murderers of three civil rights workers in 1964, just before they themselves were killed. By taking her students to view the painting, she is hoping that 'perception and imagination, self knowledge and creative expression (can be) enlivened and deepened (p.289). Abowitz's assumption is that 'aesthetic perception and moral perception are parallel capacities' (p. 294) and that the development of one will enhance the development of the other. Ladkin (2012) makes a similar case in arguing for the link between artistic practices and practices of perception and moral perception and imagination. She is focused on how moral imagination can be fostered and offers three artistic practices assumed to develop this capacity: 'staying with the senses, disinterest and imaginative free play'.

Philosophically, these ideas can be seen to be linked to the American pragmatist philosopher John Dewey and the American ethics scholar Mark Johnson. In fact, Johnson writes extensively about the similarity between moral imagination and aesthetic sensibility, suggesting that 'we are likely to learn a great deal more about morality by examining how far it is like aesthetic discrimination and artistic creation than by studying traditional moral law accounts' (Johnson, 1993, p. 210). Johnson cites four similarities between artistic activity and moral deliberation: their need for discernment, their requirement for self-expression, their investigative natures, their need for creative responses, and their requirement for skill development.

\section{Aesthetic knowing as integrative apprehension}

A fourth category of epistemologically rendered aesthetic categories notes the aesthetic's ability to cultivate holistic perception, in which the previous three perceptual 
aspects unite in an integrated whole. Abowitz (2007), Brady (1986), Koehn (2010) and Waddock (2014) all allude to a kind of 'integrative knowing' which they propose aesthetic encounters foster. Through it, perceptual enhancement, emotional connection and imaginative capacity come together in an integrated form of apprehension. This capacity of the aesthetic is apparent in the writing of the philosopher Richard Shusterman, who considers the role the body plays in aesthetic knowing, and how this knowing creates an experience of 'zestful integration'. He writes:

'Aesthetic experience is differentiated, not by its unique possession of some specific element or its unique focus on some particular dimension, but by its more zestful integration of all the elements of ordinary experience into an absorbing developing whole that provides a satisfying emotional quality' (Shusterman, 2000, p. 23) (italics mine).

Although this integrated apprehension may appear to be similar to 'perceptual awareness' it can be seen to go further to encompass emotional, and imaginative types of knowing as well. Within the business ethics literature, Waddock's systems view in which 'aesthetic sensibility highlights how the system understanding of distinctions, systems, relationships and perspectives work together (or not) tapping emotions, insights, and intuition that are necessary for creatively coming to wise actions and solutions (Waddock, 2014, p. 136.) can be seen to be aligned with such an appreciation of aesthetic knowing. In this way, critical reflexivity allows for the possibility that perceptual, emotional and imaginative knowings can be woven together into an integrative apprehension, the kind of 'Gestalt' which is also central to understanding the wholeness of ethically challenging situations. Koehn makes this point when she writes: [art] enables us to gestalt the world, opening the way for ethical insight and sounder moral reasoning' (2010, p. 220). 


\section{Aesthetic knowing as critical reflexivity}

A fifth epistemological stance highlights the aesthetic's capacity to foster critical reflexivity. Duwell (1999) and Ewenstein and Whyte ( 2007) suggest that the aesthetic prompts us to step back from our day to day experience and view it from a different, less habitually determined perspective. Ewenstein and Whyte propose, 'the aesthetic experience affords us reflexive distance from all dimensions of our practice. This leeway opens new possibilities for action, introduces new ways of looking at the world, and makes us more sensitive to human needs (p. 167). Similarly, in her autoethnographic study of her engagement with rats in art-making, Kimbell draws from Ranciere (2004) to explore the power of the aesthetic in 'expanding what can be perceived and what is thinkable' (Kimbell, 2011: 78). Certainly in that study, engaging with rats from an aesthetic viewpoint seemed to cause Kimbell to completely rethink the ethics of her initial ideas and to redevelop her project along (seemingly) more ethical lines.

It is interesting to reflect upon the role critical reflexivity plays in enabling the underlying ideologies at play within ontologically based accounts to be noticed, as well as its importance as a way of knowing from an epistemological perspective. Indeed a key project of the post-modern approach is to bring such critical insight to bear on interpretations and judgements more generally. The importance of such reflexivity in being able to harness the power of the aesthetic in relation to the ethical will be elaborated in further detail in the discussion section of the paper.

For now, however, the analysis of the literature is summarised in Figure 1, below.

[Insert Figure 1 Here] 


\section{DISCUSSION}

Increasingly within the business ethics literature scholars are engaging with 'the aesthetic' as a means of either theorizing what it is to be ethical, or how ethical capacities might be developed. This review has demonstrated the range of perspectives being brought to bear on this intersection, resulting in fragmentation and possible confusion concerning how the aesthetic might indeed inform the field. The map of the literature offers a means by which scholars can position their own perspectives and research to develop understanding further. Beyond this mapping function, the analysis indicates three additional points for further discussion.

Why turn to the aesthetic?

What is trying to be accomplished by bringing the aesthetic to bear on questions of business ethics? This provides a more detailed account than that offered by Cummings (2000) and Green (1993). In particular, from an ontological perspective the aesthetic (conceptualized as 'the beautiful') is seen to be indicative of 'the good' and therefore provides a metaphorical connection to that which is ethical. From such a perspective, that which creates 'the beautiful', in terms, for instance, of a strategy which generates harmony, balance, and resolves tension will necessarily also be 'good'. This is the notion behind Dobson's suggestion that in order to act ethically as a firm, the question, 'what is beautiful?' should be asked (Dobson, 2010).

However the review also indicates how turning to 'the beautiful' can result in aesthetic craving (Kersten, 2008; Storesletten et al 2014), resulting in ethical malfeasance. Certainly, Nazi Germany's incorporation of aesthetics as a way of manipulating the masses serves as a stark demonstration that 'the aesthetic' in itself does not necessarily lead to the 
ethical. This understanding begs the question, 'should business ethics scholars pursue 'beauty' as a guiding principle or not?'

The post modern account provides a way forward perhaps, by highlighting the role ideology plays in determining both 'the good' and 'the beautiful', and pointing out the role power plays in determining these judgements. In this way, all three conceptualizations of the aesthetic from an ontological base are needed in order for the aesthetic to serve business ethics well. Without recognizing the lure of aesthetic craving or the potential seduction of ideological framings, 'the beautiful' itself is not sufficient to provide guidance as to what might be ethical in a given situation.

\section{The Need for empirical research}

One of the most glaring revelations of the review is the lack of empirical research to substantiate claims made about the capacities of the aesthetic in relation to ethical development. None of the six empirically based articles included in this review tests links between particular aesthetically-based interventions and enhanced ethical abilities. Among the four cases studies, three use the aesthetic as a lens through which actions can be analyzed (Bathurst \& Edwards, 2011; Ewenstein \& Whyte, 2007; Kimbell, 2011) and Koehn (2014) anecdotally suggests the way in which film can be used to enhance moral imagination and critical reflexivity without robustly testing these claims. The two quantitative studies indicate that when asked, research subjects indicate that fairness and harmony are important aspects of an ethical mindset ( Issa \& Pick, 2010, 2011).

The review indicates the need for research testing claims made about the impact of different interventions and their outcomes on ethical capabilities in order that those wishing to harness the potentialities of the aesthetic from an epistemological perspective might do so in a sophisticated manner. It is interesting to speculate about whether certain kinds of 
interventions result in different ethical capacities. For instance, does increased perceptual discernment lead to enhanced ethical perception? Does the ability to connect emotionally with those in a film lead to greater compassion considering the positions of others with whom one is involved in ethical judgement making? Does enhanced system sensitivity lead people to appreciate the systems aspects of ethical decisions? The analysis presented here suggests the need to empirically test each of these linkages, in order to strengthen the case for the usefulness of the aesthetic in relation to ethical development, and to make judgements about developmental interventions wisely.

\section{The Role of Critical Reflexivity}

On both ontological and epistemological sides of the map the role of critical reflexivity as core to harnessing the power of the aesthetic in relation to the ethical is apparent. From the ontological perspective, the post modern rendering highlights the power ideologies have in shaping interpretations about both the aesthetic and the ethical. In order to discern whether or not the aesthetic is a guide to 'the good' in a certain situation, the ability to step back from the situation and recognize the underlying power dynamics, habitual modes of thinking and ideological forces which are playing their part in judgements is essential. Similarly, from the epistemological side of the map, perceptual discernment, emotional connectivity, imaginative capacity and integrative apprehension are each only possible through distanced engagement.

This kind of critical reflexivity requires attending beyond the self, its preoccupations, biases and habits of perception to be open to something apart from it. Drawing from Levinas(1969) in his exploration of the intersection of aesthetics and ethics, BlumenfeldJones proposes that the starting point for ethical engagement is the moment, 'just before we know that we know, ...when all the personhood and infinity of the person are available to us. 
(2013: 159). He suggests that this pre-knowing, in which there is a gap between that which is being perceived and the label which the self might place on it, is the critical space of ethical knowing. Blumenfeld-Jones claims that such ethical knowing can be prompted by aesthetic encounters. If this is indeed true, given the importance of critical reflexivity in all of these intersections, the aesthetic may indeed have a powerful part to play in both business ethics theorizing and the development of ethical capabilities.

\section{FURTHER RESEARCH}

The discussion leads to a re-development of the 'map of the literature' in order to indicate the way in which the post modern perspective (from the ontologically-based accounts) and critical reflexivity (from epistemologically based accounts) are aligned in a way which serves to underpin the other categories. Without the recognition of the way in which ideology shapes judgements of the aesthetic (and the ethical) the aesthetic cannot unquestionably lead to the good. Similarly, without the ability to use critical reflexivity, each of the other epistemologically based aesthetic knowings is impoverished. The map also now includes key questions for further empirically based research, which are essential to pursue if the power of the aesthetic in relation to business ethics is to be harnessed.

[Insert Figure 2 Here]

\section{CONCLUSION}

The link between 'the aesthetic' and 'the ethical' has been debated philosophically for hundreds of years. That debate entered the business ethics literature in the 1980s and the analysis of the literature shows the fragmented nature of theorizing since then. In mapping the way in which the aesthetic is being discussed in relation to business ethics this paper 
provides a comprehensive view of this territory, while also suggesting vital questions to be asked by future research. Such further study would provide a robust platform from which business ethics theorists and developers wanting to harness the power of the aesthetic in their theorizing and developmental interventions could do so with greater clarity and impact. 


\section{REFERENCES}

Abowitz, K. K. (2007). Moral Perception Through Aesthetics Engaging Imaginations in Educational Ethics. Journal of Teacher Education, 58(4), 287-298.

Arendt, H. (1998). The Human Condition (Second ed.). Chicago: University of Chicago Press.

Bathurst, R., \& Edwards, M. (2011). Carving our future in a world of possibility: Exploring contemporary implications of the Māori-Pākehā relationship in Aotearoa/New Zealand. TAMARA: Journal for Critical Organizational Inquiry, 9(3/4), 63-74.

Baumgarten, A. G. (1750). Aesthetica. Bari: Laterza.

Bleakley, A., Farrow, R., Gould, D., \& Marshall, R. (2003). Learning how to see: doctors making judgements in the visual domain. Journal of Workplace Learning, 15(7/8), 301306.

Blumenfeld-Jones, D. (2013). Johnson, Levinas, and Sensibility. In B. White \& T. Costantino (Eds.), Aesthetics, Empathy and Education (pp. 151-164). New York: Peter Lang Publishing Inc.

Brady, F. N. (1986). Aesthetic Components of Management Ethics. The Academy of Management Review, 11(2), 337-344.

Brady, F. N., \& Hart, D. W. (2006). An Aesthetic theory of conflice in administrative ethics. Administration \& Society, 38(1), 113-134.

Buck-Morss, S. (2008). Aesthetics and Anaesthetics : Walter Benjamin's Artwork Essay Reconsidered. October, 62, 3-41.

Budd, M. (2001). The Pure judgement of taste as an aesthetic reflective judgement. The British Journal of Aesthetics, 41(3), 247-260.

Burnham, D. (2000). An Introduction to Kant's Critique of Judgement. Edinburgh: Edinburgh University Press.

Caranfa, A. (2007). Lessons of solitude: The awakening of aesthetic sensibility. Journal of Philosophy of Education, 41(1), 113-127.

Carr, D. (2004). Moral values and the arts in environmental education: Towards an ethics of aesthetic appreciation. Journal of Philosophy of Education, 38(2), 221-239.

Collier, J. (2006). The Art of moral imagination: Ethics in the practice of architecture. Journal of Business Ethics, 66(2-3), 307-317.

Cummings, S. (2000). Resurfacing an aesthetics of existence as an alternative to business ethics. In The Aesthetics of Organization (pp. 212-227). London: Sage.

Dobson, J. (2007). Aesthetics as a foundation for business activity. Journal of Business Ethics, 72(1), 41-46. 
Dobson, J. (2010). Aesthetic Style as a Postructural Business Ethic. Journal of Business Ethics, 93(3), 393-400.

Dobson, J. (2014). An Aesthetic theory of the firm. In D. Koehn, D. \& Elm (Ed.), Aesthetics and Business Ethics (pp. 9-21). Dordrecht: Springer.

Duwell, M. (1999). Aesthetic experience, medical practice, and moral judgement: Critical remarks on possibilities to understand a complex relationship. Medicine, Health Care and Philosophy, 2, 161-168.

Eagleton, T. (1990). The Ideology of the Aesthetic. Malden, MA: Blackwell.

Elm, D. R. (214AD). The artist and the ethicist: Character and process. In D. Koehn, D. \& Elm (Eds.), Aesthetics and Business Ethics (pp. 53-66). Dordrecht: Springer.

Ewenstein, B., \& Whyte, J. (2007). Beyond words: Aesthetic knowledge and knowing in organizations. Organization Studies, 28(5), 689-708.

Gardiner, P. (2002). A Very Short Introduction to Kierkegaard. Oxford: Oxford University Press.

Gilligan, C. (1982). In a Different Voice: Psychological Theory and Women's Development. Cambridge MA: Harvard University Press.

Green, R. M. (1993). Business Ethics as a Postmodern Phenomenon. Business Ethics Quarterly, 3(3), 219-225.

Guillet de Monthoux, P. (2000). The Art management of aesthetic organizing. In S. Linstead \& H. Hopfl (Eds.), The Aesthetics of Organization (pp. 35-60). London: Sage.

Hancock, P. (2005). Uncovering the semiotic in organizational aesthetics. Organization, 12(1), 29-50.

Hartshorne, C. (1974). Beyond enlightened self-interest. Ethics, 84(3), 214.

Issa, T., \& Pick, D. (2010). Ethical mindsets: An Australian study. Journal of Business Ethics, 96(4), 613-629.

Issa, T., \& Pick, D. (2011). An interpretive mixed-methods analysis of ethics, spirituality and aesthetics in the Australian services sector. Business Ethics, 20(1), 45-58.

Johnson, M. (1993). Moral Imagination: Implications of Cognitive Science for Ethics. Chicago: University of Chicago Press.

Kant, I. (2005). Critique of Judgment. (trans. Bernard, E.). Mineola, N.Y.: Dover Publications.

Kateb, G. (2000). Aestheticism and morality: their cooperaton and hostility. Political Theory, 28(1), 5-38. 
Kersten, A. (2008). When craving goodness becomes bad: A critical conception of ethics and aesthetics in organizations. Culture and Organization, 14(2), 187-202.

Kierkegaard, S. (1956). Purity of Heart is to Will One Thing. New York: HarperOne.

Kimbell, L. (2011). An aesthetic inquiry into organizing some rats and some people. TAMARA: Journal of Critical Postmodern Organization Science, 9(3/4), 75-90.

Koehn, D. (2010). Ethics, morality, and art in the classroom: positive and negative relations. Journal of Business Ethics Education, 7, 213-232.

Koehn, D. (2014). Ethical darkness made visible: Michael Moore's Roger and Me. In D. Koehn, D. \& Elm (Eds.), Aesthetics and Business Ethics (pp. 83-101). Dordrecht: Springer.

Koehn, D. \& Elm, D. (2014a). Aesthetics and Business Ethics. Dordrecht: Springer.

Koehn, D. \& Elm, D. (2014b). Introduction. In D. Koehn, D. \& Elm (Eds.), Aesthetics and Business Ethics (pp. 1-5). Dordrecht: Springer.

Kohlberg, L. A. (1984). Essays on Moral Development: Vol 2. The Psychology of Moral Development: The Nature and Validity of Moral Stages. San Francisco: Harper \& Row.

Kokkos, A. (2010). Transformative learning through aesthetic experience: Towards a comprehensive method. Journal of Transformative Education, 8(3), 155-177.

Ladkin, D. (2011). The Art of "perceiving correctly": What artists can teach us about moral perception. TAMARA: Journal of Critical Postmodern Organization Science, 9(3), 91101.

Levinas, E. (1969). Totality and Infinity: An Essay in Exteriority. (A. Lingis, Ed.). Pittsburgh, PA: Duquesne University Press.

Levinson, J. (1998). Aesthetics and ethics. In J. Levinson (Ed.), Aesthetics and Ethics: Essays at the Intersection (pp. 1-25). Cambridge: Cambridge University Press.

Linstead, S., \& Hopfl, H. (2000). The Aesthetics of Organization. London: Sage.

Moberg, D. J., \& Seabright, M. A. (2000). The development of moral imagination. Business Ethics Quarterly, 10(4), 845-884.

Munro, I. (2014). Organizational ethics and Foucault's "art of living": Lessons from social movement organizations. Organization Studies, 35(8), 1127-1148.

Murdoch, I. (1970). The Sovreignty of Good. London: Routledge \& Kegan Paul Ltd.

Noddings, N. (1984). Caring: A Feminine Approach to Ethics and Moral Education. Berkeley, CA: University of California Press. 
Plato. (1966). Hippias Major. In E. F. Carritt (Ed.), Philosophies of Beauty (pp. 2-16). London: Oxford University Press.

Plotinus. (1984). Plotinus on the beautiful: Ennea 16. (trans.Taylor, E.). Godolmany, Surrey: Shrine of Wisdom.

Rabinow, P. (1986). The Foucault Reader. Hammondsworth: Penguin.

Ranciere, J. (2004). The Politics of the Aesthetic. (G. Rockhill, Ed.). London: Continuum.

Rest, J. (1986). Moral development: Advances in research and theory. New York: Praeger.

Schiller, F. (n.d.). Letters on the aesthetic education of man. (E. M. Wilkinson \& L. A. Willoughby, Eds.). Oxford: Oxford University Press.

Scitovsky, T. (1976). The Joyless Economy: The Psychology of Human Satisfaction. New York: Oxford University Press.

Shusterman, R. (2000). Performing live: Aesthetic Alternatives for the Ends of Art. Ithaca, N.Y.: Cornell University Press.

Siegel, E. (1946). Psychiatry, Economics and Aesthetics. South Deerfield, MA: Schoen.

Storsletten, V. M. L., \& Jakobsen, O. D. (2014). Development of leadership theory in the perspective of Kierkegaard's philosophy. Journal of Business Ethics, (123), 1-13.

Strati, A. (1992). Aesthetic understanding of organizational life. Academy of Management Review, 17(3), 568-581.

Strati, A. (1999). Organization and Aesthetics. London: Sage.

Taylor, S. S. (2002). Overcoming aesthetic muteness: Researching organizational members' aesthetic experience. Human Relations, 55(7), 821-840.

Taylor, S. S., \& Elmes, M. B. (2011). Aesthetics and ethics: You can't have one without the other. TAMARA: Journal of Critical Postmodern Organization Science, 9(3), 61-62.

Taylor, S. S., \& Hansen, H. (2005). Finding form: Looking at the field of organizational aesthetics. Journal of Management Studies, 42(6), 1211-1231.

Waddock, S. (2010). Finding wisdom within - The Role of seeing and reflective practice in developing moral imagination, aesthetic sensibility, and systems understanding. Journal of Business Ethics Education, 7, 177-196.

Waddock, S. (2014). Wisdom and responsible leadership: Aesthetic sensibility, moral imagination, and systems Thinking. In D. Koehn, D. \& Elm (Ed.), Aesthetics and Business Ethics (pp. 129-147). Dordrecht: Springer. 
i The relevance criteria were the following:

- Peer-reviewed scholarly articles were included;

- Book chapters from 'scholarly' publishers were included

- The content had to deal with issues concerning the inter-section of aesthetics and applied ethics (business, medicine, education)

- The content concerned the practice of ethics, as opposed to making judgements about the ethical nature of a work of art for instance. 